\title{
Research on the Business English Translation Methodology under the Perspective of Dynamic Cultural Equivalence
}

\author{
Liwen $\mathrm{Yu}^{1}$ \\ ${ }^{1}$ Jiangxi Science \& Technology Normal University, \\ Nanchang,Jiangxi, 330038 China
}

\begin{abstract}
In this paper, we conduct research on the business English translation methodology under the perspective of dynamic culture equivalence. Due to business English is the language used in business activities, therefore, the main language is characterized by simple, straightforward, concise and to the point. Dynamic equivalence theory attaches great importance to the language information receiver's feelings, emphasizes the effect of peer which requires the translation to the target language reader's role should be. Our method combines the theory with the translation procedure so that the performance of the translation activities will be more effective.
\end{abstract}

Keywords: Business English Translation; Dynamic Cultural Equivalence; Novel Methodology.

\section{Introduction}

With the acceleration of international economic integration development, English as an international language, in the international trade arena play an increasingly important role, modern business English in international trade activities play an increasingly important role in modern business English translation has been increasingly wide attention. Use English translation is more complex than normal business English translation, which requires the business English translators should not only master the professional knowledge of modern business, familiar with the translation characteristics of modern business. To translate business English well, we must fully understand the translation of all kinds of customs, culture, language countries clear the cultural differences between countries. At the same time, the translation skills for translators also should have had the certain requirements. Translators should fully understand the various business trade terms and various characteristics of business English which have a comprehensive knowledge of business English and then translate. Business English is actually in ordinary English formed on the basis of a language specialized trade. Business English from general English, and is different from the ordinary English. Business English is more difficult compared with the ordinary English, because business English description is generally more complex things [1-2].

Due to business English is the language used in business activities, therefore, the main language is characterized by simple, straightforward, concise and to the point [3]. Contracts signed the agreement reached between businessmen, pay attention to simple and clear, and business English is according to the requirements by contract, is concise, straightforward and easy to understand. Business English translation follows the principle theory. Purpose and methods of the translation is in accordance with the purposes and functions of the translation of business English translation itself is a translate the source language text into the language of this process, therefore, can be in teleological principle as the general core principles of business English translation, in different business English language environment, to adopt different and the corresponding specific standards [4]. 
In recent years, with the constant improvement of the Chinese market and Chinese market continuously go deep into the international market, Chinese market caused a large number of foreign companies. Increased the number of foreign companies, making China's talent market for business English talent demand is in constant surge in business English talent is in short supply, it will promote the development of some business English training institution. On the other hand, attracted by high pay, more and more people begin to study business English hard and this makes the business English this language has become more and more popular. It can be said that the development of modern business is inseparable from business English this language, left the business English this language, business activities between countries are difficult to smoothly. However, due to the difference of the culture, we could not always express the real meaning correctly and specifically.

In this paper, we conduct research on the business English translation methodology under the perspective of dynamic culture equivalence. Dynamic equivalence theory attaches great importance to the language information receiver's feelings, emphasizes the effect of peer, which requires the translation to the target language reader's role should be, and the role of the source language to the primitive equivalent as far as possible, with the most natural and closest equivalent to the original language. The translator does not adhere to the readers to understand the source language in the context of cultural patterns, but try to recipient and his own culture in the context of behavior. Dynamic equivalence theory emphasizes on the guided by dynamic equivalence in translation, translation criteria is the relationship between the receiver and information should be the recipient and the source language and the relationship between the original information get the same meaning. In the following sections, we will discuss this issue in detail.

\section{Our Proposed Methodology}

The Principles of Business English Translation. Business English range is very wide, some English related to the business activities can be referred to as business English, it involves fields including foreign trade, investment, international tourism, overseas investment and international transportation, etc. In addition to the field widely, which include many professional, like advertising English, legal English, business English, packaging, these all belong to the category of business English. So, along with our country foreign trade gradually, more and more people work in the business, and most is dealing with English-speaking customers, which makes the business English is widely used in foreign trade. The greatest characteristic of business English is involved in a wide range, strong professional, only a comprehensive understanding of the business English involves fields, a true understanding of business articles which can accurate translation. Therefore, the professional vocabulary, phrases accurately use is particularly important. Translators deal with various business jargon in the field of master, expand own aspect of knowledge, a lot of reading related books in the field of business. Business English translation is more economic and trade translation of documents and materials, the phrase should be strict, formal, rigorous and not with personal feelings. If the translator is not treated with caution, it will have a negative impact to the enterprise and bring both parties is difficult to estimate the loss.

After sufficient literature review, we have summarized the following existing problems that are always considered to be the most important issues need to be solved. (1) Vocabulary translation is not accurate. In business English translation, translation is not accurate often happen, this is mainly due to the lack of vocabulary, in the Chinese cannot find with the corresponding word in English, so the translation is likely to cause errors, make the language expression is not accurate. There are some words, 
connotation in both English and Chinese is different, direct translation will distort the meaning of the original. (2) Sentence translation is not accurate. Chinese attaches great importance to the thinking in images, multi-purpose said in the expression to describe one thing at a time, and highlight the main body of action, but in English translation, people pay more attention to is a kind of abstract, logical thinking, usually is one thing to make statements directly and objectively, rarely use, often use the passive voice in business communication, use of passive sentence to express, in this paper, the relevant provisions, therefore in translation we should pay attention to the differences of English and Chinese languages in the sentence.

To modify the traditional translation pattern, some related translation tricks are proposed by researchers which are shown in the following. (1) To master certain professional term translation. In business English translation, the translator should accurately put want to express something present in front of people, accurately understand the meaning of the original, to avoid confusion of vocabulary, try and keep the beauty of the article. (2) In business English translation, should pay attention to cultural differences. Due to different countries, different ethnic language and culture background, we will encounter many problems in translation, for example, expressed by the same word in different cultures have different meanings, so as a business English translator to try to strengthen their own professional knowledge accomplishment, knowledge of the cultural background of different countries, when translation according to the practical language environment to accurate translation, translation content of true meaning, to avoid the failure of the business trade caused by inaccurate translation. (3) Strengthen the communication between Chinese and western culture and fit. Due to differences in cultural background, in business English translation, the translator will encounter many unequal phenomena, which can implement translation work very well. This needs us to actively seek the similarities between Chinese and western culture, find the corresponding of both and to make the translation work can be more accurate, can be understood and accepted more easily.

The Dynamic Cultural Equivalence. In the translation activity, is very important to the process of cultural background information. Translation plays a bridge role of intercultural communication, its aim is not just to stay on the surface structure of language transformation, the main is to contain in the cultural connotation of the original work for transplantation, achieve the success of translation memes transmission. The differences of the culture could be reflected from the following perspectives. (1) Traditional culture image difference. Refers to the various nationalities in the long history of cultural imagery in the long years slowly formed a cultural symbol, most embodies the wisdom and the crystallization of the history and culture of every nation and a significant proportion of those with the legend of each nation and the period of totem worship has the close relation. As a cultural imagery memes in different cultural atmosphere, need with the aid of translation memes can be die due to the new host understood, eventually die due to the spread of the replication process successfully. (2) Way of thinking difference. Language and thought has the important relation, the expression of language is the thinking, way of thinking through language. East and west there are differences in the way of thinking, so there are large differences in language, it mainly reflects on the grammar. For example, when we language communication is always used to put the important content in the end of the conversation, while westerners will be important content in the beginning of the conversation. (3) Differences in geographic environment. Of which a nation relies for survival and language is closely related to the natural environment, national culture is also deeply marked by geographical, natural climate, people life and way of life. British and American 
countries in the western hemisphere and our country are located in the eastern hemisphere, regional differences caused the culture differences between the eastern and west and the differences of business English translation work have a certain influence. (4) Differences of religious belief. Two of the great religions of eastern and western have cultural differences. When form and content to observe in the dilemma situation, the first thing to keep the content of the equivalent effect is better. In the process of translation, must fully understand the differences of various ethnic and religious cultures in order to ensure that the source language memes accurately to the target language memes, to achieve the closest natural equivalence, thus make the cultural meme copy and distribute successfully.

Business English involves business principle, communication skills, business etiquette and cultural background, so in addition to all the general English linguistic related features, such as the pronunciation, intonation, grammar, rhetoric and so on, also has its unique language features, such as stylistic formal, careful words, etc. Application of business English purpose is to use communication skill or communicative task, so the most important characteristic for the purpose, to realize the goal of trading to persuade others to act according to own opinion. In using business English at the same time, the objectivity of abundant language use, at the same time try to avoid subjective or personal feelings color language. Therefore, the dynamic cultural equivalence is necessary.

The Translation Methodology under the Proposed Perspective. Understanding of Chinese and western cultural differences, the learning of English idioms is an important link. And idioms, thus the translation of idioms has become a difficult, if both can achieve formal equivalence in translation process and can function to equate however is good, such as under the background of the two cultures can't "be satisfactory correspondence", in this kind of information in the text pursued by the translator should also be of two kinds of discourse function equivalent language rather than between two languages in the same language. This requires the translator fully understand idioms contain cultural connotation, to moderate to grasp the elements of idioms and correct translation to the readers and the original reader's response consistent understanding of the text.

To get rid of the middle east west cultural differences affect business English translation, the first thing to improve the understanding of cultural differences between east and west. Under the impetus of the economic globalization, business English has been the rapid development, the business English translation are also put forward higher request, to meet the needs of the international economic exchanges and cooperation. The effects of differences in eastern and western cultures tend to business English translation work smoothly. Due to business English translation workers do not emphasis on the analysis of the cultural differences between east and west, there is no cross cultural practice experience, often in the translation work because something different geographical position, different way of thinking, traditional customs and national psychology with the translation. To break the things of the impact of cultural differences in business English translation, improve the level of business English major is the key. Business English professional high demand, the author thinks that the professional of business English should be divided into two parts: professional and business English professional. We firmly believe that the combination of Business English translation and dynamic cultural equivalence is necessary and will be effective.

\section{Conclusion}

In this paper, we conduct research on the business English translation methodology under the perspective of dynamic culture equivalence. Translation is a cross-language and the 
cross-cultural communicative activities pragmatic translation involves two languages the pragmatic principle of different social and cultural formation of different languages translation often encountered in pragmatic rules of pragmatic principle so that people of different cultural background in language communication when caused by cultural differences, pragmatic habits differences are inevitable facts of the resulting pragmatic failure will affect the communication of information gain communication misunderstandings that generates information errors and barriers that affect communication smoothly to cross-language cross-cultural communication success must pay attention to in the aspect of pragmatics in English and Chinese languages of the cultural differences. Our method combines the dynamic cultural equivalence into the business English translation which will be effective. In the near future, we plan to conduct more related research to enhance the current method.

\section{Acknowledgement}

This research is financially supported by the social sciences planning project (2014) in Jiangxi province (English specialized program). The project number is: $14 \mathrm{WX} 327$.

\section{References}

[1]Tomyn A J, Tyszkiewicz M D F, Norrish J M. The Psychometric Equivalence of the Personal Wellbeing Index School-Children for Indigenous and Non-Indigenous Australian Adolescents[J]. Journal of Happiness Studies, 2014, 15(1):43-56.

[2] Jing-Qian G U, Lei P F. On the Translation of Names of Scenic Spots under the Cross-cultural Communication[J]. Overseas English, 2014.

[3] Ndeffo L N, Ngwen N, Nguetse Tegoum P J, et al. Impact of equivalence scales on the spatial distribution of poverty in Cameroon: a dynamic approach[J]. Journal of Developing Areas, 2014.

[4] Quental C, Folgado J, Ambrósio J, et al. On the Equivalence Between Forward and Inverse Dynamic Analysis of Human Motion Tasks[J]. Mechanisms \& Machine Science, 2015. 